\title{
Epilepsija sergančių asmenų stigmatizacijos vertinimas
}

\author{
G. Pociuviené* \\ D. Streckyte்* \\ R. Mameniškiené** \\ *Vilniaus universiteto \\ Medicinos fakultetas \\ **Vilniaus universiteto \\ Medicinos fakultetas; \\ Vilniaus universitetas, \\ Neurologijos centras
}

Santrauka. İvadas. Nors pasaulyje epilepsija serga apie 50 milijonų žmonių, tačiau vis dar išliekantis negatyvus požiūris ị juos blogina šių asmenų gyvenimo kokybę, riboja galimybes mokytis ir dirbti. Šiuo darbu siekème ịvertinti, mūsų žiniomis, Lietuvoje iki šiol nevertintą pačių epilepsija sergančių asmenų (ESA) požiūrị ị sergančiuosius šia liga ir jų stigmatizacijos lygị.

Darbo metodika. 2019 m. spalio - $2020 \mathrm{~m}$. kovo mėnesị vykdyta anoniminė anketinė suaugusiųjų ESA apklausa. Naujai sukurtą klausimyną sudare 8 sociodemografiniai ir 20 uždaro tipo klausimų epilepsijos stigmos lygiui ịvertinti. Stigmatizacijos lygis vertintas balais: maža ar jos nèra (<33), vidutinè (33-64) ir didelè (65-100). Duomenys apdoroti „MS Excel“ ir IBM SPSS 21.0 programomis. Duomenys laikyti statistiškai reikšmingais, kai p reikšmė $<0,05$.

Rezultatai. Analizuotos 129 anketos. Tiriamujų amžiaus mediana - $36 \pm 15,8$ metų, $62 \%$ - moterys. Nors 93,8\% ESA apklaustujų yra girdeję ar skaitę apie epilepsiją $(p=0,137), 24,8 \%$ tiki, kad epilepsija yra psichikos liga $(p=0,723) ; 66,7 \%$ mano, kad epilepsija - nepagydoma ( $\mathrm{p}=0,798) ; 45 \%$ nurodè, kad visuomenè kitaip bendrauja ar elgiasi su ESA (dažniau moterys, $\mathrm{p}=0,028$ ), o 63,6 \% mano, kad ESA susiduria su sunkumais darbe ir moksle $(p=0,485)$, nepriklausomai nuo respondentų lyties. Bendras stigmatizacijos lygis: $39,3 \pm 16,5$. Stigmos balas nepriklauso nuo sociodemografinių duomenų $(p>0,05)$. Didesnè stigmatizacija yra susijusi su nuomone, kad epilepsija - psichine $(p=0,026)$ ir nepagydoma liga $(p=0,000)$. Didesnis stigmos balas silpnai koreliuoja su vyresniu amžiumi $(R=0,2$, $\mathrm{p}=0,024)$. Stigmatizacijos išreikštumas priklauso nuo nuostatos, kad ESA patiria sunkumu darbe ir moksle $(R=0,58, p=0,000)$, santykiuose $(R=0,59, p=0,000)$, visuomenè turi neigiamą išankstinị nusistatymą $(R=0,46, p=0,000)$. Stigmos lygis yra didesnis, kai ESA jaučia susirūpinimą $(R=0,5, p=0,000)$, gèdą $(R=0,55, p=0,000)$, baimę $(R=0,6, p=0,000)$, liū$\operatorname{desị~}(R=0,62, p=0,000)$ ir mano, kad yra priklausomi nuo kitų asmenų $(R=0,68, p=0,000)$.

Išvados. Lietuvos ESA stigmos išreikštumas yra vidutinis. Svarbiausias ją lemiantis veiksnys - žinių apie epilepsiją stoka: ketvirtadalis epilepsija sergančių respondentų tiki, kad epilepsija - psichikos liga, penktadalis mano, kad epilepsija nekontroliuojama liga, o du trečdaliai - kad liga nepagydoma.

Raktažodžiai: epilepsija, klausimynas, stigma, žinios.

\section{IVADAS}

Istorijos eigoje stigma jau labai seniai lydi sergančiuosius epilepsija. Ankstyviausi ịrašai - apie 1752 m. prieš mūsų erą ant akmens parašytame Hamurabio teisyne, kur surašyti draudimai sergančiajam epilepsija, tarp kurių - ir santuokos draudimas [1]. Daug amžių epilepsija laikyta psichi-

\author{
Adresas: \\ Gabriele Pociuviené \\ Vilniaus universiteto Medicinos fakultetas \\ M. K. Čiurlionio g. 21, LT-03101 Vilnius \\ El. paštas gabriele.pociuviene@santa.lt
}

kos liga, vėliau - smegenų degeneracine liga. Sergantieji epilepsija buvo aprašomi kaip žmonès su moralès trūkumu. Taip pat esama duomenų, kad epilepsija klasifikuota kaip užkrečiamoji liga [2, 3]. Senovės Graikijoje ir Senovès Romoje epilepsija buvo laikoma dievų sukelta liga, ją gydė aukojant ir atliekant įvairius religinius ritualus. Viduramžiais tikèta, kad epilepsiją sukelia piktosios dvasios, demonai, todèl sergantieji epilepsija laikyti apsėstais ir gydyti atliekant egzorcizmo seansus [3]. Epilepsija taip pat buvo siejama ir su raganyste: 1494 metų knygoje aprašoma, kad raganos turi ypatingų savybių - tokių, kaip epilepsijos priepuoliai [2]. Trečiojo Reicho metu sergantieji epilepsija, šią ligą priskiriant prie paveldimų ligų, buvo steri-

(C) Neurologijos seminarai, 2020. Open Access. This article is distributed under the terms of the Creative Commons Attribution 4.0 International License CC-BY 4.0 (http://creativecommons.org/licenses/by/4.0/), which permits unrestricted use, distribution, and reproduction in any medium, provided you give appropriate credit to the original author(s) and the source, provide a link to the Creative Commons license, and indicate if changes were made. 
lizuojami arba žudomi dujų kamerose [4]. Visą epilepsijos stigmos istoriją $1997 \mathrm{~m}$. taikliai apibendrino neurologas R. Kale, sakydamas, kad epilepsijos istorija yra 4000 metu neišprusimo, prietarų bei stigmos ir 100 paskutinių metų žinių, prietarų ir stigmos [5].

Pasaulyje epilepsija serga apie 50 milijonų žmonių [6]. Lietuvoje 2019 m. šis skaičius buvo 20 158, tai yra 7,21 atvejo 1000 gyventojų [7]. Pastaraisiais metais paskelbta bent keliolika apklausų, atliktų skirtingose valstybėse epilepsijos stigmos tema, rezultatų [8-26]. Tačiau rezultatu palyginimą sunkina tai, kad tyrimuose naudojami skirtingi klausimynai. Prieš daugiau nei du dešimtmečius sukurta Jacoby's 3-item Stigma Scale [27] yra dažniausiai naudojama stigmai vertinti ir skirta sergantiesiems epilepsija, tačiau nevertinanti tiriamụjų žinių apie epilepsiją ir jų sąsajos su stigmos lygiu. Pastaraisiais metais vis dažniau taikoma brazilų sukurta epilepsijos stigmos skalè (angl. Stigma Scale of Epilepsy, SSE), kurią sudaro 5 uždaro tipo klausimai [9].

Remdamiesi kas kelerius metus atliekamų tyrimų ir stigmai mažinti skirtų edukacinių programų patirtimi ir poreikiu $[19,28]$ bei tuo, kad, mūsų žiniomis, Lietuvoje toks tyrimas nėra atliktas, išsikèlėme tikslą įvertinti pačių epilepsija sergančių asmenų požiūrị ị sergančiuosius šia liga ir jų stigmatizacijos lygį.

\section{TIRIAMIEJI IR TYRIMO METODAI}

\section{Tyrimo dalyviai}

2019 m. spalio - 2020 m. kovo mėnesį VUL SK Epilepsijos ir miego sutrikimų kabinete atlikta anoniminė anketiné suaugusių (18 m. ir vyresnių) epilepsija sergančių asmenų, atvykusių ambulatorinei konsultacijai, apklausa. İ tyrimą neįtraukti asmenys, nesutinkantys dalyvauti apklausoje ir nesugebantys atsakyti ị klausimus (nesuprantantys lietuviškai, turintys sąmonès, suvokimo sutrikimų, protinę negalią ir kt.).

\section{Tyrimo metodai}

Leidimą tyrimui atlikti išdavė Vilniaus universiteto ligoninès Santaros klinikų Etikos komitetas (Nr. GR-6575).

Tyrimo dalyviai pildè anoniminę naujai autorių parengtą anketą, sudarytą iš 8 sociodemografinių ir 20 uždaro tipo klausimų epilepsijos stigmos lygiui ịvertinti. Stigmos lygis buvo skaičiuojamas balais. Kuo didesnis gautas balas, tuo stipresnis yra stigmatizacijos lygis. Maksimalus anketoje surinktų balų skaičius - 54 , balai perskaičiuoti 100 balų sistemoje ir toliau straipsnyje pateikiami šia forma, kad būtų galima palyginti su kitų studijų rezultatais. Stigmatizacijos lygis klasifikuotas taip: iki 33 balų - maža stigmatizacija, 33-64 balai - vidutinè ir 65-100 balų - didelè stigmatizacija.

\section{Statistinis apdorojimas}

Statistikai apskaičiuoti naudotos „MS Excel“ ir IBM SPSS 21.0 programos. Aprašomoji statistika naudota vidurkiams ir standartiniams nuokrypiams apskaičiuoti. Ryšiui tarp lyties, gyvenamosios vietos, išsilavinimo, žinioms apie epilepsiją ir ịvairiems klausimams apie epilepsiją ịvertinti naudotas koreliacijos koeficientas. Kintamojo pasiskirstymui grupėse patikrinti - chi kvadrato testas, tikslusis Fišerio kriterijus. Duomenys laikyti statistiškai reikšmingais, kai p reikšmė $<0,05$.

1 lentelè. Sociodemografiniai duomenys

\begin{tabular}{|c|c|c|c|c|c|c|}
\hline \multicolumn{2}{|c|}{ Sociodemografiniai duomenys } & $\begin{array}{c}\text { Visi ESA } \\
\mathbf{N}=129 \mathrm{~N}(\%)\end{array}$ & $\begin{array}{c}\text { Vyrai } \\
N=49 N(\%)\end{array}$ & $\begin{array}{c}\text { Moterys } \\
\mathbf{N}=\mathbf{8 0} \mathbf{N}(\%)\end{array}$ & p reikšmé* & $\begin{array}{c}\text { Koreliacija } \\
\text { R reikšmė (p reikšmė) }\end{array}$ \\
\hline \multirow[t]{5}{*}{ Išsilavinimas } & Pradinis & $4(3,1 \%)$ & $1(2 \%)$ & $3(3,8 \%)$ & \multirow[t]{5}{*}{$p=0,147$} & \multirow[t]{5}{*}{$\mathrm{R}=0,18(\mathrm{p}=0,044)$} \\
\hline & Vidurinis & $38(29,5 \%)$ & $18(36,7 \%)$ & $20(25 \%)$ & & \\
\hline & Profesinis & $30(23,3 \%)$ & $14(28,6 \%)$ & $16(20 \%)$ & & \\
\hline & Nebaigtas aukštasis & $11(8,5 \%)$ & $5(10,2 \%)$ & $6(7,5 \%)$ & & \\
\hline & Aukštasis & $46(35,6 \%)$ & $11(22,5 \%)$ & $35(43,7 \%)$ & & \\
\hline \multirow[t]{5}{*}{ Užimtumas } & Dirba & $70(54,3 \%)$ & $24(49 \%)$ & $46(57,5 \%)$ & \multirow[t]{5}{*}{$p=0,615$} & \multirow[t]{5}{*}{$R=-0,06(p=0,472)$} \\
\hline & Mokosi & $7(5,4 \%)$ & $4(8,2 \%)$ & $3(3,8 \%)$ & & \\
\hline & Studijuoja & $9(7 \%)$ & $4(8,2 \%)$ & $5(6,2 \%)$ & & \\
\hline & Bedarbis & $29(22,5 \%)$ & $10(20,3 \%)$ & $19(23,8 \%)$ & & \\
\hline & Pensininkas & $14(10,9 \%)$ & $7(14,3 \%)$ & $7(8,7 \%)$ & & \\
\hline \multirow[t]{2}{*}{ Gyvenamoji vieta } & Miestas & $107(83 \%)$ & $39(79,6 \%)$ & $68(85 \%)$ & \multirow[t]{2}{*}{$p=0,428$} & \multirow[t]{2}{*}{$R=-0,07(p=0,432)$} \\
\hline & Kaimas & $22(17 \%)$ & $10(20,4 \%)$ & $12(15 \%)$ & & \\
\hline \multirow{2}{*}{$\begin{array}{l}\text { Yra skaitę, girdèję } \\
\text { apie epilepsiją }\end{array}$} & Taip & $121(93,8 \%)$ & $44(89,8 \%)$ & $77(96,3 \%)$ & \multirow[t]{2}{*}{$p=0,137$} & \multirow[t]{2}{*}{$\mathrm{R}=-0,13(\mathrm{p}=0,142)$} \\
\hline & $\mathrm{Ne}$ & $8(6,2 \%)$ & $5(10,2 \%)$ & $3(3,7 \%)$ & & \\
\hline \multirow[t]{2}{*}{ Yra matę priepuolị } & Taip & $61(47,3 \%)$ & $20(40,8 \%)$ & $41(51,2 \%)$ & \multirow[t]{2}{*}{$p=0,249$} & \multirow[t]{2}{*}{$\mathrm{R}=-0,1(\mathrm{p}=0,253)$} \\
\hline & $\mathrm{Ne}$ & $68(52,7 \%)$ & $29(59,2 \%)$ & $39(48,8 \%)$ & & \\
\hline
\end{tabular}

*Priklausomybè tarp ESA respondentų (vyrų ir moterų) grupių ir ịvairių sociodemografinių faktorių. 


\section{REZULTATAI}

Vertintos 129 epilepsija sergančių asmenų (ESA) respondentų anketos. Tiriamųjų amžiaus mediana - $36 \pm 15,8$ metų, $62 \%$ apklaustujų sudarė moterys. Sociodemografiniai tiriamųjų duomenys pateikiami 1 lentelèje.
2 lenteleje pateikiamos respondentų nuomonès apie epilepsiją.

ESA emocijos ir jausmai, patiriami matant priepuolius, pateikiami 3 lentelèje.

Bendras stigmatizacijos vidurkis - 39,3 $\pm 16,5$. Epilepsijos stigmatizacijos lygis pateikiamas 4 lentelèje.

2 lentelè. Respondentų nuomonès apie epilepsiją

\begin{tabular}{|c|c|c|c|c|c|c|}
\hline \multicolumn{2}{|c|}{ Teiginiai ir atsakymo pasirinkimas } & $\begin{array}{c}\text { Visi ESA } \\
\mathrm{N}=129 \mathrm{~N}(\%)\end{array}$ & $\begin{array}{c}\text { Vyrai } \\
N=49 N(\%)\end{array}$ & $\begin{array}{c}\text { Moterys } \\
\mathbf{N}=\mathbf{8 0 ~ N}(\%)\end{array}$ & p reikšmé* & $\begin{array}{c}\text { Koreliacija } \\
\mathbf{R} \text { reikšmė (p reikšmė) }\end{array}$ \\
\hline \multirow{2}{*}{$\begin{array}{l}\text { Epilepsija - psichikos } \\
\text { liga }\end{array}$} & Taip & $32(24,8 \%)$ & $13(26,5 \%)$ & $19(23,8 \%)$ & \multirow[t]{2}{*}{$\mathrm{p}=0,723$} & \multirow[t]{2}{*}{$R=-0,03(p=0,725)$} \\
\hline & $\mathrm{Ne}$ & $97(75,2 \%)$ & $36(73,5 \%)$ & $61(76,2 \%)$ & & \\
\hline \multirow{4}{*}{$\begin{array}{l}\text { Epilepsija - } \\
\text { kontroliuojama liga }\end{array}$} & Visiškai ne & $27(20,9 \%)$ & $11(22,5 \%)$ & $16(20 \%)$ & \multirow[t]{4}{*}{$p=0,451$} & \multirow[t]{4}{*}{$R=-0,1(p=0,92)$} \\
\hline & Iš dalies & $67(51,9 \%)$ & $26(53,1 \%)$ & $41(51,3 \%)$ & & \\
\hline & Didele dalimi & $26(20,2 \%)$ & $7(14,2 \%)$ & $19(23,7 \%)$ & & \\
\hline & Visiškai taip & $9(7 \%)$ & $5(10,2 \%)$ & $4(5 \%)$ & & \\
\hline \multirow{2}{*}{$\begin{array}{l}\text { Epilepsija - išgydoma } \\
\text { liga }\end{array}$} & Taip & $43(33,3 \%)$ & $17(34,7 \%)$ & $26(32,5 \%)$ & \multirow[t]{2}{*}{$\mathrm{p}=0,798$} & \multirow[t]{2}{*}{$\mathrm{R}=0,02(\mathrm{p}=0,799)$} \\
\hline & $\mathrm{Ne}$ & $86(66,7 \%)$ & $32(65,3 \%)$ & $54(67,5 \%)$ & & \\
\hline \multirow{2}{*}{$\begin{array}{l}\text { Visuomenė kitaip elgia- } \\
\text { si, bendrauja su ESA }\end{array}$} & Taip & $58(45 \%)$ & $16(32,6 \%)$ & $42(52,5 \%)$ & \multirow[t]{2}{*}{$\mathrm{p}=0,028$} & \multirow[t]{2}{*}{$\mathrm{R}=0,19(\mathrm{p}=0,021)$} \\
\hline & $\mathrm{Ne}$ & $71(55 \%)$ & $33(67,4 \%)$ & $38(47,5 \%)$ & & \\
\hline \multirow{3}{*}{$\begin{array}{l}\text { Kaip jaustųsi, jei arti- } \\
\text { masis gyventų su ESA? }\end{array}$} & Neprieštarautų & $74(57,4 \%)$ & $28(57,2 \%)$ & $46(57,5 \%)$ & \multirow[t]{3}{*}{$p=0,516$} & \multirow[t]{3}{*}{$\mathrm{R}=0,03(\mathrm{p}=0,764)$} \\
\hline & Būtų neramu & $49(38 \%)$ & $20(40,8 \%)$ & $29(36,3 \%)$ & & \\
\hline & Prieštarautų & $6(4,6 \%)$ & $1(2 \%)$ & $5(6,2 \%)$ & & \\
\hline \multirow{2}{*}{$\begin{array}{l}\text { ESA susiduria su sun- } \\
\text { kumais darbe, moksle }\end{array}$} & Taip & $82(63,6 \%)$ & $33(67,3 \%)$ & $49(61,3 \%)$ & \multirow[t]{2}{*}{$\mathrm{p}=0,485$} & \multirow[t]{2}{*}{$\mathrm{R}=0,14(\mathrm{p}=0,123)$} \\
\hline & $\mathrm{Ne}$ & $47(36,4 \%)$ & $16(32,7 \%)$ & $31(38,7 \%)$ & & \\
\hline
\end{tabular}

*Ryšys tarp respondentų grupių (vyrų ir moterų) ir nuomonės apie epilepsiją.

3 lentelè. Emocijos ir jausmai, matant epilepsijos priepuolio ištiktą asmeni

\begin{tabular}{|c|c|c|c|c|c|}
\hline \multicolumn{2}{|c|}{ Ką jaučia, matydami priepuolị? } & \multirow{2}{*}{$\begin{array}{c}\text { Visi ESA } \\
\mathbf{N}=\mathbf{1 2 9} \mathbf{N}(\%)\end{array}$} & \multirow{2}{*}{\begin{tabular}{|c|}
$\begin{array}{c}\text { Vyrai } \\
\mathbf{N}=49 \mathbf{N}(\%)\end{array}$ \\
$9(18,4 \%)$ \\
\end{tabular}} & \multirow{2}{*}{$\begin{array}{c}\begin{array}{c}\text { Moterys } \\
\mathbf{N}=\mathbf{8 0} \mathbf{N}(\%)\end{array} \\
9(11,3 \%) \\
\end{array}$} & \multirow{2}{*}{$\begin{array}{l}\text { p reikšmé } \\
p=0,112\end{array}$} \\
\hline Baimę & Visiškai ne & & & & \\
\hline & Iš dalies & $61(47,3 \%)$ & $27(55,1 \%)$ & $34(42,5 \%)$ & \\
\hline & Didele dalimi & $21(16,3 \%)$ & $7(14,3 \%)$ & $14(17,5 \%)$ & \\
\hline & Visiškai taip & $29(22,5 \%)$ & $6(12,2 \%)$ & $23(28,7 \%)$ & \\
\hline \multirow[t]{4}{*}{ Liūdesị } & Visiškai ne & $25(19,4 \%)$ & $12(24,5 \%)$ & $13(16,3 \%)$ & \multirow[t]{4}{*}{$\mathrm{p}=0,356$} \\
\hline & Iš dalies & $65(50,3 \%)$ & $20(40,8 \%)$ & $45(56,2 \%)$ & \\
\hline & Didele dalimi & $26(20,2 \%)$ & $12(24,5 \%)$ & $14(17,5 \%)$ & \\
\hline & Visiškai taip & $13(10,1 \%)$ & $5(10,2 \%)$ & $8(10 \%)$ & \\
\hline \multirow[t]{4}{*}{ Gailestị } & Visiškai ne & $18(13,9 \%)$ & $7(14,3 \%)$ & $11(13,8 \%)$ & \multirow[t]{4}{*}{$\mathrm{p}=0,843$} \\
\hline & Iš dalies & $57(44,2 \%)$ & $20(40,8 \%)$ & $37(46,2 \%)$ & \\
\hline & Didele dalimi & $25(19,4 \%)$ & $9(18,4 \%)$ & $16(20 \%)$ & \\
\hline & Visiškai taip & $29(22,5 \%)$ & $13(26,5 \%)$ & $16(20 \%)$ & \\
\hline \multirow{2}{*}{$\begin{array}{l}\text { Kaip elgtųsi, pamatę } \\
\text { epilepsijos priepuolį? }\end{array}$} & Padètu & $113(87,6 \%)$ & $45(91,8 \%)$ & $68(85 \%)$ & \multirow[t]{2}{*}{$\mathrm{p}=0,194$} \\
\hline & Tokia situacija išgąsdintų, pasitrauktų & $16(12,4 \%)$ & $4(8,2 \%)$ & $12(15 \%)$ & \\
\hline
\end{tabular}

4 lentelè. Epilepsijos stigmatizacijos lygis

\begin{tabular}{|c|c|c|c|c|c|}
\hline Stigmatizacijos lygis & $\begin{array}{c}\text { Visi ESA } \\
\mathbf{N}=129 \mathbf{N}(\%) \\
\end{array}$ & $\begin{array}{c}\text { Vyrai } \\
N=49 N(\%)\end{array}$ & $\begin{array}{c}\text { Moterys } \\
\mathbf{N}=\mathbf{8 0} \mathbf{N}(\%) \\
\end{array}$ & p reikšmè & $\begin{array}{c}\text { Koreliacija } \\
\text { R reikšmė (p reikšmė) }\end{array}$ \\
\hline Mažas (<33 balai) & $47(36,4 \%)$ & $18(36,8 \%)$ & $29(36,3 \%)$ & \multirow[t]{3}{*}{$p=0,216$} & \multirow[t]{3}{*}{$\mathrm{R}=0,07(\mathrm{p}=0,434)$} \\
\hline Vidutinis (33-65 balai) & $73(56,6 \%)$ & $30(61,2 \%)$ & $43(53,7 \%)$ & & \\
\hline Didelis ( $\geq 65$ balai) & $9(7 \%)$ & $1(2 \%)$ & $8(10 \%)$ & & \\
\hline
\end{tabular}


5 lentelè. ESA patiriamų jausmų ir sunkumų įvairiose srityse dažnis

\begin{tabular}{|c|c|c|c|c|c|c|}
\hline \multicolumn{2}{|c|}{ Patiriami jausmai ir sunkumai } & \multirow{2}{*}{\begin{tabular}{|l} 
Dažnis \\
Niekada \\
\end{tabular}} & \multirow{2}{*}{$\begin{array}{c}\text { Visi ESA } \\
\mathbf{N}=\mathbf{1 2 9} \mathbf{N}(\boldsymbol{\%})\end{array}$} & \multirow{2}{*}{$\begin{array}{c}\begin{array}{c}\text { Vyrai } \\
\mathbf{N}=\mathbf{4 9} \mathbf{N}(\%)\end{array} \\
16(32,7 \%)\end{array}$} & \multirow{2}{*}{$\begin{array}{c}\text { Moterys } \\
\mathbf{N}=\mathbf{8 0 ~ N}(\%) \\
32(40 \%) \\
\end{array}$} & \multirow{2}{*}{$\begin{array}{l}\text { p reikšmè } \\
p=0,077\end{array}$} \\
\hline \multirow{20}{*}{$\begin{array}{l}\text { Kaip daznaı ESA } \\
\text { susiduria su sunku- } \\
\text { mais įvairiose } \\
\text { srityse? }\end{array}$} & \multirow[t]{4}{*}{ Santykiai } & & & & & \\
\hline & & Kartais & $55(42,6 \%)$ & $27(55,1 \%)$ & $28(35 \%)$ & \\
\hline & & Dažnai & $22(17,1 \%)$ & $6(12,2 \%)$ & $16(20 \%)$ & \\
\hline & & Visada & $4(3,1 \%)$ & $0(0 \%)$ & $4(5 \%)$ & \\
\hline & \multirow[t]{4}{*}{ Darbas } & Niekada & $33(25,6 \%)$ & $9(18,4 \%)$ & $24(30 \%)$ & \multirow[t]{4}{*}{$p=0,224$} \\
\hline & & Kartais & $44(34,1 \%)$ & $18(36,7 \%)$ & $26(32,5 \%)$ & \\
\hline & & Dažnai & $37(28,7 \%)$ & $18(36,7 \%)$ & $19(23,7 \%)$ & \\
\hline & & Visada & $15(11,6 \%)$ & $4(8,2 \%)$ & $11(13,8 \%)$ & \\
\hline & \multirow[t]{4}{*}{ Mokslas } & Niekada & $47(36,4 \%)$ & $12(24,5 \%)$ & $35(43,7 \%)$ & \multirow[t]{4}{*}{$p=0,059$} \\
\hline & & Kartais & $41(31,8 \%)$ & $22(44,9 \%)$ & $19(23,8 \%)$ & \\
\hline & & Dažnai & $35(27,1 \%)$ & $13(26,5 \%)$ & $22(27,5 \%)$ & \\
\hline & & Visada & $6(4,7 \%)$ & $2(4,1 \%)$ & $4(5 \%)$ & \\
\hline & \multirow{4}{*}{$\begin{array}{l}\text { Seksualiniai } \\
\text { santykiai }\end{array}$} & Niekada & $76(58,9 \%)$ & $28(57,1 \%)$ & $48(60 \%)$ & \multirow[t]{4}{*}{$\mathrm{p}=0,411$} \\
\hline & & Kartais & $37(28,7 \%)$ & $17(34,7 \%)$ & $20(25 \%)$ & \\
\hline & & Dažnai & $11(8,5 \%)$ & $2(4,1 \%)$ & $9(11,3 \%)$ & \\
\hline & & Visada & $5(3,9 \%)$ & $2(4,1 \%)$ & $3(3,7 \%)$ & \\
\hline & \multirow{4}{*}{$\begin{array}{l}\text { Išankstinis } \\
\text { neigiamas } \\
\text { nusistatymas }\end{array}$} & Niekada & $35(27,1 \%)$ & $11(22,5 \%)$ & $24(30 \%)$ & \multirow[t]{4}{*}{$p=0,611$} \\
\hline & & Kartais & $64(39,6 \%)$ & $28(57,1 \%)$ & $36(45 \%)$ & \\
\hline & & Dažnai & $24(18,6 \%)$ & $8(16,3 \%)$ & $16(20 \%)$ & \\
\hline & & Visada & $6(4,7 \%)$ & $2(4,1 \%)$ & $4(5 \%)$ & \\
\hline \multirow{4}{*}{\multicolumn{2}{|c|}{ Kaip dažnai jaučia susirūpinimą? }} & Niekada & $12(9,3 \%)$ & $8(16,3 \%)$ & $4(5 \%)$ & \multirow[t]{4}{*}{$p=0,066$} \\
\hline & & Kartais & $62(48,1 \%)$ & $25(51 \%)$ & $37(46,3 \%)$ & \\
\hline & & Dažnai & $39(30,2 \%)$ & $13(26,6 \%)$ & $26(32,5 \%)$ & \\
\hline & & Visada & $16(12,4 \%)$ & $3(6,1 \%)$ & $13(16,2 \%)$ & \\
\hline \multirow{4}{*}{\multicolumn{2}{|c|}{ Kaip dažnai jaučia gèdą? }} & Niekada & $52(40,3 \%)$ & $21(42,9 \%)$ & $31(38,8 \%)$ & \multirow[t]{4}{*}{$\mathrm{p}=0,353$} \\
\hline & & Kartais & $55(42,6 \%)$ & $21(42,9 \%)$ & $34(42,5 \%)$ & \\
\hline & & Dažnai & $17(13,2 \%)$ & $7(14,2 \%)$ & $10(12,5 \%)$ & \\
\hline & & Visada & $5(3,9 \%)$ & $0(0 \%)$ & $5(6,2 \%)$ & \\
\hline \multirow{4}{*}{\multicolumn{2}{|c|}{ Kaip dažnai jaučia baimę? }} & Niekada & $20(15,5 \%)$ & $13(26,5 \%)$ & $7(8,8 \%)$ & \multirow[t]{4}{*}{$p=0,016$} \\
\hline & & Kartais & $60(46,5 \%)$ & $22(44,9 \%)$ & $38(47,5 \%)$ & \\
\hline & & Dažnai & $38(29,5 \%)$ & $13(26,5 \%)$ & $25(31,2 \%)$ & \\
\hline & & Visada & $11(8,5 \%)$ & $1(2 \%)$ & $10(12,5 \%)$ & \\
\hline \multirow{4}{*}{\multicolumn{2}{|c|}{ Kaip dažnai jaučia liūdesį? }} & Niekada & $30(23,3 \%)$ & $18(36,7 \%)$ & $12(15 \%)$ & \multirow[t]{4}{*}{$\mathrm{p}=0,025$} \\
\hline & & Kartais & $62(48,1 \%)$ & $22(44,9 \%)$ & $40(50 \%)$ & \\
\hline & & Dažnai & $32(24,8 \%)$ & $8(16,3 \%)$ & $24(30 \%)$ & \\
\hline & & Visada & $5(3,9 \%)$ & $1(2 \%)$ & $4(5 \%)$ & \\
\hline Kaip dažnai jaučia, & rad yra priklausomi & Niekada & $42(32,6 \%)$ & $16(32,7 \%)$ & $26(32,5 \%)$ & $\mathrm{p}=0,362$ \\
\hline nuo kitų? & & Kartais & $47(36,4 \%)$ & $17(34,7 \%)$ & $30(37,5 \%)$ & \\
\hline & & Dažnai & $29(22,5 \%)$ & $14(28,5 \%)$ & $15(18,8 \%)$ & \\
\hline & & Visada & $11(8,5 \%)$ & $2(4,1 \%)$ & $9(11,2 \%)$ & \\
\hline
\end{tabular}

\section{Stigmatizacija ir sociodemografiniai duomenys}

Didelị stigmatizacijos lygị nustatème $8(10 \%)$ moterims ir $1(2 \%)$ vyrui $(\mathrm{p}=0,216)$, jis nepriklausè nuo gyvenamosios vietos $(p=0,881)$, išsilavinimo $(p=0,355)$, užimtumo $(\mathrm{p}=0,088)$ ir respondentų žinių apie epilepsiją $(\mathrm{p}=0,722)$, tačiau vyresni asmenys buvo labiau stigmatizuojami nei jaunesni $(\mathrm{R}=0,2, \mathrm{p}=0,024)$.

\section{Stigmatizacija ir žinios apie epilepsiją}

Didesnis stigmos balas silpnai koreliavo su nuomone, kad epilepsija - psichikos $(\mathrm{R}=0,23, \mathrm{p}=0,01)$ ir nepagydoma liga $(\mathrm{R}=0,37, \mathrm{p}=0,000)$. Iš $32(24,8 \%)$ tikinčių, kad epilepsija yra psichikos liga, 5 (15,6\%) turejo dideli stigmatizacijos lygi (palyginimui - didelis stigmatizacijos balas nustatytas $4,1 \%$ galvojančių, kad epilepsija - ne psichinė 
liga), $\mathrm{p}=0,026$. Didelę stigmatizaciją turèjo 9,3\% manančių, kad epilepsija yra išgydoma (palyginimui - 2,3\% tikinčių, kad epilepsija nepagydoma liga), $\mathrm{p}=0,000$. $6(4,6 \%)$ ESA prieštarautų, kad jų artimasis gyventų su ESA, tačiau tik $1(16,7 \%)$ iš jų turèjo didelę stigmatizaciją (5,4\% tų, kurie neprieštarautų), $p=0,013$. Nustatėme silpną, bet teigiamą koreliaciją tarp stigmatizacijos išreikštumo ir nuomonès, kad visuomenė kitaip elgiasi ir bendrauja su ESA ( $R=0,37, p=0,000)$. Nustateme, kad beveik ketvirtadalis $(22,2 \%)$ labiau stigmatizuotų ESA yra nelinkę padèti kitam priepuolio metu (palyginimui - tik 4,4\% mažiau stigmatizuotų ESA nepadètų kitam priepuolio metu), $\mathrm{p}=0,152$.

\section{Stigmatizacija ir emocijos bei jausmai, patiriami priepuoliu metu ar matant priepuolius}

Ryškiai stigmatizuoti asmenys patiria didesnę baimę $(\mathrm{R}=0,33, \mathrm{p}=0,000)$, liūdesi $(\mathrm{R}=0,5, \mathrm{p}=0,000)$ ir gailestị $(\mathrm{R}=0,45, \mathrm{p}=0,000)$, matydami epilepsijos priepuolių ištiktą žmogų.

\section{Stigmatizacija ir ESA patiriamų sunkumų dažnis}

Didesnis stigmatizacijos lygis vidutiniškai stipriai koreliavo su nuomone, kad ESA patiria sunkumų darbe ir moksle $(\mathrm{R}=0,58, \mathrm{p}=0,000)$, santykiuose $(\mathrm{R}=0,59, \mathrm{p}=0,000)$, seksualiniuose santykiuose $(R=0,41, p=0,000)$ ir su neigiamu išankstiniu nusistatymu prieš ESA $(R=0,46$, $\mathrm{p}=0,000)$. Kiek daugiau nei dešimtadaliui $(11 \%)$ respondentų, manančių, kad ESA susiduria su sunkumais dirbdami ir mokydamiesi, nustatyta didelè stigmatizacija. Grupèje respondentų, kurie nesusiduria su sunkumais dirbdami ir mokydamiesi, aukštai stigmatizuotų asmenų nebuvo $(\mathrm{p}=0,000)$. Didesnè stigmatizacija yra susijusi su nuomone, kad ESA dažnai jaučia susirūpinimą $(R=0,5$, $\mathrm{p}=0,000)$, gèdą $(\mathrm{R}=0,55, \mathrm{p}=0,000)$, baimę $(\mathrm{R}=0,6$, $\mathrm{p}=0,000)$, liūdesi $(\mathrm{R}=0,62, \mathrm{p}=0,000)$ ir yra priklausomi nuo kitų asmenų $(\mathrm{R}=0,68, \mathrm{p}=0,000)$.

Duomenys apie ESA patiriamų jausmų ir sunkumų dažni pateikti 5 lentelèje.

\section{REZULTATŲ APTARIMAS}

Savo tyrimu nustateme, kad ESA bendras stigmos lygio vidurkis - 39,3 $\pm 16,5$. Tai yra vidutinio lygio stigmatizacijos balas. Toki pat balą (39,5 balo) gavo ir tyrẻjai Italijoje [8], o Brazilijoje šis skaičius buvo saikingai didesnis $46 \pm 18,22$ [9]. Manoma, kad tokị ESA požiūrio ị sergančiuosius epilepsija skirtumą lemia sociokultūriniai šalių ypatumai, taip pat sveikatos sistemos tvarka ir skirtingas respondentu išsilavinimas bei religingumas. Baker $2000 \mathrm{~m}$. publikuotame tyrime, kuriame dalyvavo daugiau kaip 5000 respondentų iš 15 Europos valstybių (Lietuva ị ši tyrimą nebuvo ịtraukta), stigmatizuoti buvo $51 \%$ respondentų, o $18 \%$ ESA nurode jaučiantys didelę stigmatizaciją [19]. Stigmos išreikštumas šiame tyrime buvo ver- tintas naudojant stigmos skalę, sudarytą iš trijų teiginių: jaučiu, kad dèl epilepsijos kiti žmonès jaučiasi nejaukiai, būdami šalia; jaučiu, kad kiti asmenys mane vertina kaip žemesnès kokybės asmeni, ir jaučiu, kad kai kurie žmonès vengia manęs dèl mano ligos (epilepsijos), ị kuriuos tiriamieji rinkosi atsakymą „Taip“ arba „Ne“. Mažiausiai stigmatizuotų ESA buvo Ispanijoje, o daugiausia - gyvenančių Prancūzijoje. Didesnis stigmatizacijos lygis koreliavo su nerimu, neigiama nuostata, ilgalaikemis sveikatos problemomis, traumomis ir nepageidaujamu vartojamų vaistų poveikiu [19]. Mūsų tyrime didelį stigmatizacijos lygị nurodè tik $7 \%$ respondentų. Tokius rezultatus galimai lemia pačių ESA požiūris ị save, kaip savarankiškus, savimi pasitikinčius asmenis, ir geros jų žinios apie epilepsiją (93,8 \% visų respondentų yra skaitę apie epilepsiją ar domėjęsi ja). Daugiau ryškiai stigmatizuotų buvo moterų, jos reikšmingai dažniau negu vyrai nurodè manančios, kad visuomenė kitaip elgiasi ir bendrauja su ESA, taip pat reikšmingai dažniau nurodė manančios, kad ESA dažnai jaučia baimę ir liūdesį. Tokị jų požiūrị galima būtų aiškinti prielaida, kad tyrimų rezultatais moterys yra linkusios būti labiau empatiškos, geriau suprasti neverbalinę kūno kalbą [29]. Taip pat respondentų atsakymus apie ESA savijautą lemia jų asmeninis santykis su liga - priepuolių nenuspèjamumo faktas, epilepsijos kontrolès efektyvumas pacientams kelia nerimo ir baimès jausmus.

Daugiau negu pusė mūsų tyrimo respondentų nurodè manantys, kad epilepsija yra neišgydoma liga. Tokị dideli skaičių galètų paaiškinti tai, kad tyrime dalyvavo pacientai, tuo metu buvę gydymo įstaigoje, o ị VUL SK Epilepsijos ir miego sutrikimų kabinetą dažniausiai kreipiasi asmenys, kuriems priepuoliai kartojasi ar yra sunkiai kontroliuojami. Tai gali būti esminis mūsų tyrimo trūkumas, kadangi šio tyrimo imties nuomonè neatspindi visų ESA požiūrio. Tačiau iš tyrimų rezultatų matome, kad ESA žinios apie savo ligą gerejja - $2013 \mathrm{~m}$. apklausos duomenimis, epilepsiją, kaip nekontroliuojamą ligą, nurode $24,6 \%$ (dabar - 20,9\%), o 43,3 \% ESA nurodė manantys, kad epilepsija yra psichinė liga ar tokios ligos simptomas (mūsų tyrime taip manančių skaičius sumažèjo beveik perpus - iki 24,8 \%) [30]. Kadangi žinių apie epilepsiją trūkumas ir to keliamas nerimas galimai didina šios ligos stigmatizacijos lygị [19], pacientų švietimas galètų būti viena esminių stigmos mažinimo priemonių.

Kaip ir 2017 m. atliktoje stigmos tyrimų metaanalizèje [31], mes taip pat nenustatėme reikšmingų koreliacijų tarp respondentų amžiaus, lyties ir stigmos lygio, tačiau stebėjome tiesioginị ryšį tarp stigmos lygio ir susirūpinimo, gèdos, baimès bei liūdesio jausmų $(\mathrm{p}<0,05)$.

\section{Tyrimo tęstinumas}

Būtų tikslinga ši tyrimą pratęsti ir ịvertinti ESA gyvenimo kokybę, kadangi ESA nurodomas stigmos dydis yra reikšmingai susijęs su blogesne gyvenimo kokybe, sunkesniais depresijos simptomais ir didesniu gydymui atsparios epilepsijos dažniu [8]. Tam galètų būti naudojamas specializuotas ESA skirtas klausimynas QOLIE-31 (angl. Quality 
of Life in Epilepsy-31) [32], patikimas ir plačiai tyrimuose naudojamas Beck depresijos klausimynas (angl. Beck Depression Inventory II, BDI-II), skirtas depresijos simptomams įvertinti, atskiriant juos nuo neretai panašių nerimo sutrikimo sukeliamų simptomų [33], ir gyvenimo kokybės klausimynas SF-36 [34], siekiant gautus duomenis, tiriant ESA, palyginti su bendros populiacijos gyvenimo kokybės įverčiais. Lyginant epilepsijos stigmos skalès rezultatus su gyvenimo kokybės įvertinimo (naudojant QQV-65 klausimyną) rezultatais, gaunama reikšminga neigiama koreliacija [9]. Kitame tyrime daugybinès regresijos analizė parodè, kad gyvenimo kokybės ịvertis ir QOLIE-31 klausimyno dalis „Socialinė funkcija“ yra reikšmingiausi epilepsijos stigmos dydi numatantys faktoriai [8].

\section{IŠVADOS}

Svarbiausias veiksnys, lemiantis ESA stigmatizaciją, yra visuomenès žinių apie epilepsiją stoka: ketvirtadalis epilepsija sergančių respondentų tiki, kad epilepsija - psichikos liga, penktadalis mano, kad epilepsija - nekontroliuojama liga, o du trečdaliai - kad liga nepagydoma.

\section{Literatūra}

1. International League Against Epilepsy. The history and stigma of epilepsy. Epilepsia 2003; 44: 12-4. https://doi.org/ 10.1046/j.1528-1157.44.s.6.2.x

2. Tuft M, Nakken KO. Epilepsy as stigma - evil, holy or mad? Tidsskr Nor Laegeforen 2014; 134(23-24): 2328-31. https://doi.org/10.4045/tidsskr.14.0872

3. Diamantis A, Sidiropoulou K, Magiorkinis E. Epilepsy during the Middle Ages, the Renaissance and the Enlightenment. J Neurol 2010; 257(5): 691-8. https://doi.org/10.1007/ s00415-009-5433-7

4. Martin M, Fangerau H, Karenberg A. German neurology and the 'Third Reich'. Eur Neurol 2016; 76: 234-43. https://doi.org/10.1159/000450851

5. Kale R. Bringing epilepsy out of the shadows. BMJ 1997; 315(7099): 2-3. https://doi.org/10.1136/bmj.315.7099.2

6. World Health Organization. Epilepsy: a public health imperative [Internet]. 2019 [cited $2020 \mathrm{Apr}$ 20]. Available from: https://www.who.int/publications-detail/epilepsy-apublic-health-imperative

7. Higienos institutas. Prieiga per internetą: https://stat.hi.lt/ default.aspx?report_id=168 [Žiūrèta 2020-05-02].

8. Tombini M, Assenza G, Quintiliani L, Ricci L, Lanzone J, De Mojà R, et al. Epilepsy-associated stigma from the perspective of people with epilepsy and the community in Italy. Epilepsy Behav 2019; 98(Pt A): 66-72. https://doi.org/10.1016/ j.yebeh.2019.06.026

9. Fernandes PT, Salgado PC, Noronha AL, Sander JW, Li LM. Stigma scale of epilepsy: validation process. Arq Neuropsiquiatr 2007; 65(Suppl 1): S35-42. https://doi.org/ 10.1590/S0004-282X2007001000006

10. Baybaş S, Yıldırım Z, Ertem DH, Dirican A, Dirican A. Development and validation of the stigma scale for epilepsy in Turkey. Epilepsy Behav 2017; 67: 84-90. https://doi.org/ 10.1016/j.yebeh.2016.12.023
11. Mbuba CK, Abubakar A, Odermatt P, Newton CR, Carter JA. Development and validation of the Kilifi Stigma Scale for Epilepsy in Kenya. Epilepsy Behav 2012; 24(1): 81-5. https://doi.org/10.1016/j.yebeh.2012.02.019

12. Elafros MA, Bowles RP, Atadzhanov M, Mbewe E, Haworth A, Chomba E, et al. Reexamining epilepsy-associated stigma: validation of the Stigma Scale of Epilepsy in Zambia. Qual Life Res 2015; 24(6): 1483-9. https://doi.org/ 10.1007/s11136-014-0868-4

13. Brabcová D, Kohout J, Potužák D, Beňová $\mathrm{B}$, Kršek $\mathrm{P}$. Psychometric properties of the Czech version of the Stigma Scale of Epilepsy. PLoS One 2018; 13(3): e0195225. https://doi.org/10.1371/journal.pone.0195225

14. Lee SA, Choi EJ, Jeon JY, Paek JH. Attitudes toward epilepsy and perceptions of epilepsy-related stigma in Korean evangelical Christians. Epilepsy Behav 2017; 74: 99-103. https://doi.org/10.1016/j.yebeh.2017.06.013

15. Bielen I, Friedrich L, Sruk A, Prvan MP, Hajnšek S, Petelin Z, et al. Factors associated with perceived stigma of epilepsy in Croatia: a study using the revised Epilepsy Stigma Scale. Seizure 2014; 23(2): 117-21. https://doi.org/ 10.1016/j.seizure.2013.10.008

16. Yue Z, Ma C, Lim KS, Xiao B, Wu Q, Shu Y, et al. Validation of the Chinese version of public attitudes toward epilepsy scale in Mainland China. Epilepsy Behav 2017; 72: 150-5. https://doi.org/10.1016/j.yebeh.2017.04.028

17. Holmes E, Bourke S, Plumpton C. Attitudes towards epilepsy in the UK population: Results from a 2018 national survey. Seizure 2019; 65: 12-9. https://doi.org/10.1016/j.seizure. 2018.12.012

18. Young GB, Derry P, Hutchinson I, John V, Matijevic S, Parrent L, et al. An epilepsy questionnaire study of knowledge and attitudes in Canadian college students. Epilepsia 2002; 43: 652-8. https://doi.org/10.1046/j.1528-1157. 2002.01002.x

19. Baker GA, Brooks J, Buck D, Jacoby A. The stigma of epilepsy: a European perspective. Epilepsia 2000; 41(1): 98-104. https://doi.org/10.1111/j.1528-1157. 2000.tb01512.x

20. Luna J, Nizard M, Becker D, Gerard D, Cruz A, Ratsimbazafy V, et al. Epilepsy-associated levels of perceived stigma, their associations with treatment, and related factors: a cross-sectional study in urban and rural areas in Ecuador. Epilepsy Behav 2017; 68: 71-7. https://doi.org/ 10.1016/j.yebeh.2016.12.026

21. Rafael F, Houinato D, Nubukpo P, Dubreuil CM, Tran DS, Odermatt $\mathrm{P}$, et al. Sociocultural and psychological features of perceived stigma reported by people with epilepsy in Benin. Epilepsia 2010; 51(6): 1061-8. https://doi.org/10.1111/ j.1528-1167.2009.02511.x

22. Winkler AS, Mayer M, Schnaitmann S, Ombay M, Mathias B, Schmutzhard E, et al. Belief systems of epilepsy and attitudes toward people living with epilepsy in a rural community of northern Tanzania. Epilepsy Behav 2010; 19(4): 596-601. https://doi.org/10.1016/j.yebeh. 2010.09 .023

23. O'Neill S, Irani J, Siewe Fodjo JN, et al. Stigma and epilepsy in onchocerciasis-endemic regions in Africa: a review and recommendations from the onchocerciasis-associated epilepsy working group. Infect Dis Poverty 2019; 8: 34. https://doi.org/10.1186/s40249-019-0544-6

24. Peterson CL, Walker C, Shears G. The social context of anxiety and depression: exploring the role of anxiety and depression in the lives of Australian adults with epilepsy. Epilepsy 
Behav 2014; 34: 29-33. https://doi.org/10.1016/j.yebeh. 2014.03.005

25. Noble AJ, Robinson A, Marson AG. Are "Theory of Mind" skills in people with epilepsy related to how stigmatised they feel? An exploratory study. Behav Neurol 2016; 2016: 5025174. https://doi.org/10.1155/2016/5025174

26. Gzirishvili N, Kasradze S, Lomidze G, Okujava N, Toidze O, de Boer HM, et al. Knowledge, attitudes, and stigma towards epilepsy in different walks of life: a study in Georgia. Epilepsy Behav 2013; 27(2): 315-8. https://doi.org/10.1016/ j.yebeh.2013.02.011

27. Jacoby A. Felt versus enacted stigma: a concept revisited. Evidence from a study of people with epilepsy in remission. Soc Sci Med 1994; 38(2): 269-74. https://doi.org/10.1016/ 0277-9536(94)90396-4

28. Cui W, Kobau R, Zack MM, Buelow JM, Austin JK. Recent changes in attitudes of US adults toward people with epilepsy - results from the 2005 SummerStyles and 2013 FallStyles surveys. Epilepsy Behav 2015; 52(Pt A): 108-18. https://doi.org/10.1016/j.yebeh.2015.08.040

29. Fischer AH, Kret ME, Broekens J. Gender differences in emotion perception and self-reported emotional intelligence: a test of the emotion sensitivity hypothesis. PLoS One 2018; 13(1): e0190712. https://doi.org/10.1371/journal.pone. 0190712

30. Sakalauskaitė-Juodeikienė E, Mameniškienė R. Epilepsija sergančių pacientų žinios apie jų ligą: skersinio pjūvio tyrimas Vilniaus epileptologijos centre. Neurologijos seminarai 2013; 17(58): 278-87.

31. Shi Y, Wang S, Ying J, Zhang M, Liu P, Zhang H, et al. Correlates of perceived stigma for people living with epilepsy: a meta-analysis. Epilepsy Behav 2017; 70(Pt A): 198-203. https://doi.org/10.1016/j.yebeh.2017.02.022

32. Cramer JA, Perrine K, Devinsky O, Bryant-Comstock L, Meador K, Hermann B. Development and cross-cultural translations of a 31-item quality of life in epilepsy inventory. Epilepsia 1998; 39(1): 81-8. https://doi.org/10.1111/j.15281157.1998.tb01278.x

33. Beck AT, Steer RA, Carbin MG. Psychometric properties of the Beck Depression Inventory: twenty-five years of evaluation. Clin Psychol Rev 1988; 8(1): 77-100. https://doi.org/ 10.1016/0272-7358(88)90050-5

34. Ware JE Jr, Sherbourne CD. The MOS 36-item short-form health survey (SF-36). I. Conceptual framework and item selection. Med Care 1992; 30(6): 473-83. https://doi.org/ 10.1097/00005650-199206000-00002

\section{G. Pociuvienė, D. Streckytė, R. Mameniškienė}

\section{ASSESSMENT OF STIGMATIZATION IN PEOPLE WITH EPILEPSY}

\section{Summary}

Introduction. Although 50 million people worldwide have epilepsy, the prevalent negative attitudes towards them impair their quality of life and limit opportunities to study and work. To our knowledge, epilepsy stigmatization has not been studied in Lithuania. For this reason, we aimed to assess the attitudes to epilepsy and epilepsy stigmatization in people with epilepsy (PWE).

Methods. In October 2019-March 2020, adult PWE completed a newly developed anonymous questionnaire composed of 8 socio-demographic and 20 closed-ended questions to assess epilepsy stigma. Stigmatization was assumed to be non-existing or low at $<33$ points, average at 33-64 and high at $65-100$ points. MS Excel and IBM SPSS 21.0 were used for statistical analysis. Statistical significance was assumed at $\mathrm{p}<0.05$.

Results. 129 completed questionnaires were analyzed. Mean age of the subjects was $36 \pm 15.8$ years; $62 \%$ were women. Although $93.8 \%$ of PWE have heard/read about epilepsy ( $p=0.137$ ), $24.8 \%$ of them believe that epilepsy is a mental illness ( $\mathrm{p}=0.723)$; $66.7 \%$ think that epilepsy is incurable $(\mathrm{p}=0.798) ; 45 \%$ reported that society treats PWE differently (more often women, $\mathrm{p}=0.028)$, and $63.6 \%$ think that PWE face difficulties working and studying $(\mathrm{p}=0.485)$. Mean stigma score is $39.3 \pm 16.5$. The score does not depend on socio-demographic data $(\mathrm{p}>0.05)$. A higher score weakly correlates with older age $(\mathrm{R}=0.2$, $\mathrm{p}=0.024$ ), although higher stigma scores correlate with the opinion that epilepsy is a mental $(\mathrm{p}=0.026)$ and incurable illness $(p=0.000)$. Respondents with a higher stigmatization score are more likely to think that PWE face difficulties working or studying $(\mathrm{R}=0.58, \mathrm{p}=0.000)$ and in relationships $(\mathrm{R}=0.59, \mathrm{p}=0.000)$ as well as that society has a preconceived negative attitude towards PWE $(R=0.46, p=0.000)$. Stigma level is higher when PWE feel anxiety $(\mathrm{R}=0.5, \mathrm{p}=0.000)$, shame $(\mathrm{R}=0.55, \mathrm{p}=0.000)$, fear $(\mathrm{R}=0.6, \mathrm{p}=0.000)$, sadness $(\mathrm{R}=0.62, \mathrm{p}=0.000)$ and consider to be depended on other individuals $(\mathrm{R}=0.68, \mathrm{p}=0.000)$.

Conclusions. Lack of knowledge about epilepsy is possibly the main reason for epilepsy stigmatization at the average level: a quarter of respondents with epilepsy believe that epilepsy is a mental illness, more than a fifth believe that epilepsy cannot be controlled and two-thirds believe that it cannot be cured.

Keywords: epilepsy, questionnaire, stigma, knowledge.

Gauta:

20200512

Priimta spaudai: 20200514 